\title{
INTENTION TO CONTRIBUTE IN CORPORATE WAQF: APPLYING THE THEORY OF PLANNED BEHAVIOUR
}

\author{
Nurul Adilah Hasbullah ${ }^{1 *}$, Khairil Faizal Khairi ${ }^{2}$, Muhammad Ridhwan Ab. Aziz ${ }^{3}$ \\ ${ }^{1}$ Postgraduate Student, Faculty of Economics and Muamalat, Universiti Sains Islam Malaysia (USIM). \\ ${ }^{2,3}$ Lecturers, Faculty of Economics and Muamalat, Universiti Sains Islam Malaysia (USIM). \\ *Corresponding author: n.adilahasbullah@gmail.com
}

Article history

Received:30/03/2015

Received in revised form:04/08/2015

Accepted: 04/08/2015

\begin{abstract}
Corporate waqf has contributed a great change into the waqf system as a whole and been generally accepted as a way of waqf practice. However, the literature that discusses about the factors influencing people to contribute or involve in this practice is very limited. Prior to action, intention is taken place. Therefore, this study aims to examine the factors influencing people's intention to contribute in corporate waqf, particularly to the employees of Majlis Agama Islam Wilayah Persekutuan (MAIWP), based on the theory of planned behaviour (TPB). A set of a questionnaire was constructed in order to measure the validity of the theory towards people's intention in contributing for corporate waqf. The result of this study found that attitude, subjective norm and perceived behavioural control were significantly related to intention to contribute in corporate waqf among people.
\end{abstract}

Keywords: Corporate Waqf, Intention to Contribute in Corporate Waqf, Theory of Planned Behaviour 


\title{
1.0 INTRODUCTION
}

Literally, the word waqf derived from the Arabic word waqafa that means restrain (al-habs) or prevent (al-man) (Mahamood, 2007; Borham, 2011 and Ab Rahman, 2009). Legally, waqf is a holding certain property, preserving it for the confined benefit of certain philanthropy and prohibiting any use or disposition of it outside its specific objective (Kahf, 2003). On the other hand, corporate waqf is one of the instruments in waqf system, which is the confinement of an amount of liquid money, shares, profit, dividends by founder (s) such as individuals, companies, corporations, organisations or institutions, and the dedication of its usufruct in perpetuity to the welfare of society (Abdel Mohsin, 2014).

Generally, corporate waqf is the application of waqf in the context of modern business and corporate activities, whereby the benefits allocation derived from the share investment dividend, membership fees and reinvestment dividend. In the long term, corporate waqf indirectly transforms the business and corporate activities so that it can be operated with more Islamic techniques than the existing practices. For instance, this waqf is an innovation in a contemporary style, has never been explored and is suitable with the globalisation nowadays. From the law perspective, waqf in form of share is permissible in Shariah since it is in line with the principles and concept of waqf in Islam (Borham, 2011).

According to the data provided by Yayasan Waqaf Malaysia (YWM), the fund collected from corporate waqf until 2013 was RM97, 000. It was indeed a very small amount out of total amount of waqf of RM986, 257, in which the total corporate waqf fund was based on nine companies only. If more companies jointly contribute in corporate waqf, the amount will increase. Initially, corporate waqf was implemented by the corporate companies only. However, if the participation on the corporate waqf was open to public or individual also, it would increase the total collection of corporate waqf as a whole.

Besides that, intention is an important element to influence one's action. If it does not exist, nothing shall take place. Islam also emphasizes the intention of doing something due to anyone who intends to do a good deeds and then he or she is prevented to do so by reason of an illness such as sick or death, then surely he is rewarded with what he intended. Umar al-Khattab (r.a.) narrated that the Prophet (p.b.u.h.) said:

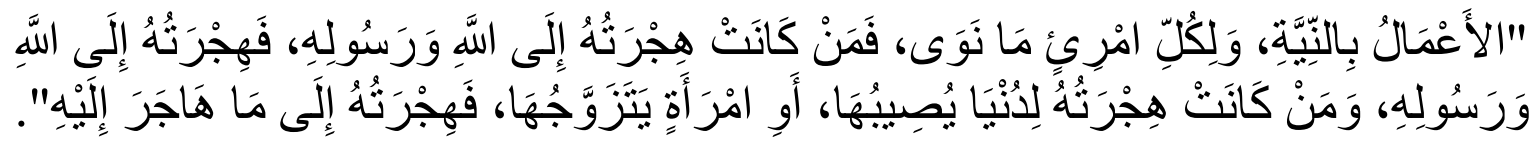

\begin{abstract}
"Deeds are (a result) only of the intentions (of the actor), and an individual is (rewarded) only according to that which he intends. Therefore, whosoever has emigrated for the sake of Allah and His messenger, then his emigration was for Allah and His messenger. Whosoever emigrated for the sake of worldly gain, or a woman (whom he desires) to marry, then his emigration is for the sake of that which (moved him) to emigrate".
\end{abstract}

(Narrated by Bukhari and Muslim, Book 2, Hadith 47)

In the TPB, the main focus is behavioural intention as a precursor to the actual behaviour (Osman, 2014). According to Osman (2014) also, the factors that influence one's behaviour, such as attitude, subjective norms and perceived behaviour control, where it works through intention to affect whether one would actually act on the intention or not.

Even though the TPB widely used in many area of researches (Ali et al., 2014; Linden, 2011; Simon et al., 2012; Truong, 2009; Shien, 1998; Lim et al., 2011; Lee et al., 2010; Susan and Chen, 2011; Nguyen, 2011; Blanchard et al., 2003; Cote et al., 2012; Kurland, 1995; Teo and Lee, 2010; Mullan and Wong, 2010; Xiao and $\mathrm{Wu}, 2006)$, but it validity has not yet to be proven in the area of corporate waqf as to whether attitude, subjective norms and perceived behavioural control are possible determinants in predicting the behavioural intention of Muslims to contribute in corporate waqf. Osman (2014) conducted the study regarding cash waqf participation among young intellectuals. However, due to the nature of his data, the model his applied was not generalized to corporate waqf. Therefore, this study aims to examine the effectiveness of these theories in the 
context of corporate waqf and whether factors such theory can be used as factors that can affect the intention of Muslims to contribute in corporate waqf.

The researchers are interested to study the TPB in the area of corporate waqf when looking at the excellence of the Johor Corporation Berhad (JCorp) in managing their corporate waqf property where RM3.15 million of 131,765 million of shares are waqf by their subsidiaries was allocated for Fisabilillah activities in year 2013 (Annual Report WANCorp, 2014). At the same time, found that very few works have been written on the recent creation of corporate waqf. This study was conducted in Malaysia due to JCorp as pioneer of corporate waqf which known today. Absolutely, Malaysia has many experts in this field that easier for the researchers to refer. At the same time, the role of corporate waqf was admitted by government as an instrument of socioeconomic development with referring to the Budget Planning 2013 (Mahmood, 2013). The government itself was recognized the corporate waqf since entrusted Yayasan Wakaf Malaysia (YWM) under the Jabatan Wakaf, Zakat dan Haji (JAWHAR) to draw up a master plan for corporate waqf with study legal structure of each Majlis Agama Islam Negeri (MAIN).

Since this study is the first study which proves the validity of the TPB in the area of corporate endowments, absolutely it will provide some contributions for the many parties. Among them is the study could be increasing the number of the literature in this field due to it is used regression analysis in investigating the factors influencing Muslim's intention to contribute in corporate waqf.

Besides that, this study also could help the government in diversifying the existing efforts by making corporate $w a q f$ as a tool to achieve an economics balance between the races that will lead to the restructuring of community in Malaysia. Based on the research findings, the government will able to find the solution as a policy could be implemented to improve people's intention especially Muslims to contribute in corporate waqf. Indirectly, it can make a contribution towards corporate waqf industry also.

\subsection{LITERATURE REVIEW AND HYPOTHESES DEVELOPMENT}

TPB attempts to explain what predicts behavioural intention, which in turn, predicts the actual behaviour (Lim et al., 2011). TPB was proposed by Ajzen (1991) as an extension of Ajzen and Fishbein's theory of reasoned action (Fishbein \& Ajzen, 1975). Moreover, TPB postulates three conceptually independent determinants of intention, which are attitude, subjective norm and perceived behavioural control (Ajzen, 1991). Even though the TPB is widely used in many area of studies, but its validity has not been proven in the area of corporate waqf. The factors of TPB should examine in the context of waqf especially corporate waqf because it can be a guideline in order to explore what are the factors may influencing Muslim's intention to contribute in corporate waqf.

Behavioural Intention: Fishbein \& Ajzen (1975) define intention as a subjective probability to carry out behaviour. They are indications of how hardly people are willing to try, and how much of an effort they are planning to exert in order to perform the behaviour (Ajzen, 1991). In other words, if people have stronger intention to engage in the behaviour, then they are more likely to perform it. Due to its robust ability to predict behavior, which is the central goal of behavioural intention models, it has been used as a dependent variable in many studies (Osman, 2014). Understanding intentions is particularly useful as phenomena are relatively rare (Norris \& Alan, 1993). As mentioned earlier, Ajzen (1991) states that human intention is guided by three types of antecedents, namely attitude, subjective norm and perceived behavioural control. The theoretical framework of this study is shown in Figure 1.

Attitude: Attitude is one of the predictors in the TPB. Ajzen (1991) mentions that attitude is important to predict and explain human behaviour. It also refers to the degree to which a person has a favourable or unfavourable evaluation or appraisal of the behaviour in question (Ali et al., 2014). Lim et al. (2011) strengthens the foundation of attitude by saying that it is composed of the individual's salient belief about perceived consequences of performing the behaviour. Numerous studies have documented the significant relationship between attitude and intention (Ajzen, 1991; Osman, 2014; Ali et al., 2014; Linden, 2011; Simon, 2012; Truong, 2009; Shien, 1998, Lim et al., 2011, Lee et al., 2010; Susan \& Chen, 2011; Teo \& Lee, 2010 and Xiao \& Wu, 2006). Other than that, Simon (2012) suggests that increasing positive attitudes towards charitable giving may encourage donation. Therefore, the researchers want to test whether the factor of attitude is applicable in influencing Muslim's intention to contribute 
in corporate waqf. If a Muslims have positive attitude towards corporate waqf, then the possibility they will contribute in corporate waqf is high. The first hypothesis for this study is:

H1: There is a positive relationship between attitude and people's intention to contribute in corporate waqf.

Subjective Norm: Subjective norm is another predictor of the TPB. It was developed by Fishbein \& Ajzen (1975), which refers to external and interpersonal influence. Ajzen (1991) and (Ali et al., 2014) define subjective norm as the perceived social pressure whether or not the behaviour should be performed. This variable consists of two measures, namely normative belief, referring to doing what other people want someone to do and the motivation complying with important referents (Nguyen, 2011). The importance of subjective norms on behavioural intention has been revealed in the literature across disciplines (Ajzen, 1991; Osman, 2014; Linden, 2011; Truong, 2009; Shien, 1998, Lim et al., 2011, Lee et al., 2010; Susan \& Chen, 2011 and Teo \& Lee, 2010). Therefore, the researchers are curious wants to know whether the subjective norm variable can be used in this study. If subjective norm of Muslims is positive, thus the probability they will contribute in corporate waqf is also high. The second hypothesis for this study is:

H2: There is a positive relationship between subjective norm and people's intention to contribute in corporate waqf.

Perceived Behavioural Control: Another factor that determines people's intention to act based of the TPB is perceived behavioural control. According to Ajzen (1991), perceived behaviour control is people's perception of the ease or difficulty of performing the behaviour of interest. It is assumed to reflect past experience as well as anticipated impediment and obstacle (Ali et al., 2014). Fundamentally, Osman (2014) mentioned that the more favourable the attitude and subjective norm with respect to behaviour, and the greater the perceived behavioural control, the stronger should be an individual's intention to perform behaviour. Most of the studies found that perceived behavioural control is significant predictor towards intention (Ajzen, 1991; Osman, 2014; Linden, 2011; Simon, 2012; Truong, 2009; Shien, 1998, Lee et al., 2010 and Xiao \& Wu, 2006). The result of the study that was conducted by Truong (2009) found that the relationship between perceived behavioural control and intention to use was the strongest compared to other factors. Therefore, the researchers want to test whether the factor of perceived behavioural control can contributed the same outcomes towards Muslim's intention to contribute in corporate waq. If perceived behaviour control of Muslims is positive, then they will become potential founders in corporate waqf. The third hypothesis for this study is:

H3: There is a positive relationship between perceived behavioural control and people's intention to contribute in corporate waqf.

\subsection{RESEARCH METHODOLOGY}

This study was conducted at MAIWP as they are one of the institutions that practices corporate waqf system. Their employees were found suitable to answer the research questions of this study due to all of them are Muslims and they are already aware and familiar with the corporate waqf practice, therefore they will becomes potential founders for the corporate waqf's contribution. Indirectly, they have the answer what are the factors influencing them to contribute in corporate waqf. The data for this study were collected through questionnaire from 148 respondents. The questionnaires are distributed by Corporate Unit of MAIWP by adopted simple random sampling. The questionnaire using Likert's scales (from $1=$ strongly disagree to $5=$ strongly agree) was adapted from various relevant studies such as Ramayah et al. (2009), Gopi \& Ramayah (2007) and Shih \& Fang (2004). The time horizon used was one-shot or cross-sectional studies which data gathered just once. This method has the least bias and offers the most generalizability (Sekaran, 2003).

The researchers using Statistical Package for Social Science (SPSS) version 20 in order to conduct frequency analysis, descriptive analysis, reliability and multiple regressions' analysis. Frequency analysis is used to extract the percentile of the profiles of respondents in terms of gender, age, education and salary. Mean and standard deviation are computed for descriptive analysis. The reliability test is used to examine the internal consistency 
among the items in their respective factors. The multiple regression analysis is particularly used to test the hypotheses proposed earlier.

\subsection{RESULT}

A total of 148 questionnaires were completed and valid at a successful return rate $74 \%$. As presented in Table 1, most respondents are female, which represent 67.6 percent while male represent only 32.4 percent. Out of 148 respondents, 45.3 percent represent age from 31 to 40 years and only 0.7 percent represents age from 61 to 70 years. Based on education, 42.6 percent of the respondents are graduated from secondary school and below while only 0.7 percent of the respondents are Ph.D holder. Subsequently, most of the respondents earned RM2,000 to RM3,000 monthly salary with 68.2 percent while the least respondents earned RM5,001 to RM6,000 with 2.0 percent.

Table 2 demonstrates the descriptive analysis results. Firstly, the item of 'performing corporate waqf course is rewarding' score the highest of 4.08; meaning that it is the most influential factor for attitude variable. The standard deviation of 0.71 shows how much variation or dispersion existed from its mean. Secondly, the item of 'it is expected of me that I should perform corporate waqf' scored the highest value of 3.99; meaning that it is the most influential factor for subjective norm variable. The standard deviation of 0.82 shows how much variation or dispersion existed from its mean. Next, for perceived behavioural control, the item of 'I have knowledge to perform corporate waqf' scored the highest value of 3.85. It shows that most of the respondents had the knowledge to perform corporate waqf. Moreover, the standard deviation of 0.87 shows how much variation or dispersion existed from its mean and the item of 'I will think opting corporate waqf' of the highest mean value scored 4.19. The standard deviation of 0.68 shows how much variation or dispersion existed from its mean.

Besides that, Table 3 illustrates the result of reliability test, whereby the Cronbach's alpha reliability coefficient was obtained for all the variables. Most of the variables are above 0.70 , and it is considered acceptable to measure for this study. Out of four variables, three are above 0.90, except for the attitude with 0.89 . The other variable variables, which are subjective norm, perceived behavioural control and intention to contribute scored $0.94,0.95$ and 0.91. The reliability of the measure indicates the stability and the instrument measure concept, and as a conclusion, coefficient was obtained from all questions in Likert's Scale are reliable.

Meanwhile, for the multiple regression analysis, the correlation coefficient $r$ indicates the strength of relationship between two variables. This gives us no idea of how much of the variance in the dependent or criterion variable can be explained when several independent variables are theorised to simultaneously influence it (Sekaran, 2003). Table 4 demonstrates the results of the regression analysis through Model Summary Table showing that 0.559 or $55.9 \%$ of the variance in the dependent variable (intention to contribute) were explained by the independent variables (attitude, subjective norm and perceived behaviour control).

Table 5 illustrates the regression analysis results through coefficients table. Attitude is significantly associated with people's intention to contribute in corporate $\operatorname{waqf}(t=5.94, p=0.00)$. Hence, $\mathrm{H} 1$ is supported. The role of the attitude in influencing people's intention has been supported by the research conducted by Sommer (2011), which mentioned that the intentions more strongly based on attitudes ("more desirability based") offer better prediction of behaviour. This was strengthened by Fen and Sabaruddin (2008), the more favourable one's attitude (be it instrumental or affective) towards exercising, the greater likelihood of that person to engage in exercise behavior. Similar with this study, the more favourable one's attitude towards corporate waqf, the greater likelihood of that person to engage in corporate waqf's contribution.

It also shows that subjective norm is significantly related to people's intention to contribute in corporate waqf $(t=3.43, p=0.01)$, which $\mathrm{H} 2$ is supported. The role of the subjective norm in influencing people's intention has been supported by the research conducted Mukhtar and Butt (2012) which reported subjective norm appears to be the strongest of all the predictors for choosing Halal products. This was strengthened by Tolma et al. (2006) which mentioned that subjective norm was the strongest predictor of intention. Therefore, it indicates that the subjective norm will be a valuable factor in influencing Muslim's intention to contribute in corporate waqf. 
Furthermore, perceived behavioural control is not significantly related to people's intention to contribute in corporate waqf $(\mathrm{t}=1.75, \mathrm{p}=0.08)$, and that means $\mathrm{H} 3$ is not supported. This results also supported by the study conducted by Teo and Lee (2010) which found that the perceived behavioural control is not significant predictor of behavioural intention. This means perceived behavioural control is not the predictor that influencing Muslim's intention to contribute in corporate waqf. Eventhough a Muslims have high levels of perceived behavioural control, it is not the factor that tend them to involve in corporate waqf's contribution. Two of the three determinants were found to be significant predictors, which namely attitude and subjective norm. The summary of the regression analysis results is shown in Figure 2.

\subsection{CONCLUSIONS AND DISCUSSION}

The purpose of this study was to examine the factors that influencing people's intention to contribute in corporate waqf, particularly the employees of MAIWP. This study has empirically tested three factors which are attitude, subjective norm and perceived behavioural control. This study showed that attitude and subjective have significant effect on behavioural intention to contribute in corporate waqf, while perceived behavioural control did not. This study also found that the attitude is the strongest factor. Indirectly, this study provide some theoretical contributions in the area of corporate waqf where develop a new research model in investigating the factors influencing intention to contribute. This study also has limitations. The sample of this study is relatively small, which used 148 respondents only. The researchers chose the employees at MAIWP and it was not a longitudinal study in nature. Thus, future research is encouraged in order to gain more samples to ensure the results obtained are more accurate. The same study should also be conducted in every region of Malaysia to ensure the results obtained can be generalised to other Malaysians and carried out in longitudinal to determine the predictive role of intentions in actual corporate waqf contribution.

\section{REFERENCES}

Ab Rahman, A. (2009). "Peranan Wakaf dalam Pembangunan Ekonomi Umat Islam dan Aplikasinya di Malaysia.” Jurnal Syariah. Vol. 17: pp. 113-152.

Abdel Mohsin, M. I. (2014). Corporate Waqf from Principle to Practice. Kuala Lumpur: Pearson.

Ajzen, I. (1991). “The Theory of Planned Behaviour”. Organizational Behaviour and Human Process. Vol. 50. (2): pp. 179-211.

Ali, S., Md Zani, R. and Kasim, K. (2014). "Intention - Behaviour Relations: A Conceptual and Literature Review". Research Journal of Finance and Accounting. Vol. 5. (19).

Annual Report WANCorp 2014. (2014). Accesed from <http://wancorp.com.my/wpcontent/uploads/2015/05/Laporan-Tahunan-2014-Published.compressed.pdf>, accessed date: 13 Januari 2015

Blanchard, C. M., Courneya, K. S, Rodgers, W. M., Fraser, S. N., Murray, T. C., Daub, B. and Black, B. (2003). "Is the Theory of Planned Behaviour a Useful Framework for Understanding Exercise Adherence During Phase II Cardiac Rehabilitation?” Journal of Cardiopulmonary Rehabilitation. Vol. 23: pp. 29-39.

Book 2, Hadith 47 <http://altahleel.com/hadith-explorer/search?time=1432094700〉

Borham, A.S. (2011). Pelaksanaan Pembangunan Wakaf Korporat Johor Corporation Berhad (JCorp): Satu Tinjauan. (Proposal). International Conference on Humanities 2011.

Cote, F., Gagnon, J., Houme, P. K., Abdeljelil, A. B. and Gagnon, M. -P. (2012). "Using the Theory of Planned Behaviour to Predict Nurses' Intention to Integrate Research Evidence into Clinical Decision-Making". Journal of Advanced Nursing. Vol. 68 (10): pp. 2289-2298. 
Fen, Y. S and Sabaruddin, N. A. (2008). "An Extended Model of Theory of Planned Behaviour in Predicting Exercise Intention”. International Business Research. Vol. 1 (4): pp. 108 -122.

Fishbein, M. and Ajzen, I. (1975). "Belief, Attitude, Intention and Behaviour: An Introduction to Theory and Research". Reading, MA: Addison-Wesley.

Gopi, M. and Ramayah, T. (2007). "Applicability of Theory of Planned Behaviour in Predicting Intention to Trade Online: Some Evidence from a Developing Country". International Journal of Emerging Markets. Vol. 2. (4): pp. 348-360.

Kahf, M. (2003). "The Role of Waqf in Improving the Ummah Welfare". Paper presented at International Seminar on Waqf as Private Legal Body. Medan, Indonesia. 6-7 January 2003.

Kurland, N. B. (1995). "Ethical Intentions and the Theories of Reasoned Action and Planned Behavior". Journal of Applied Social Psychology. Vol. 25 (4): pp. 297-313.

Lee, J., Cerreto, F. A. and Lee, J. (2010). "Theory of Planned Behavior and Teachers' Decisions Regarding Use of Educational Technology”. Educational Technology \& Society. Vol. 13. (1): pp. 152-164.

Lim, Y. M., Yap, C. S. and Lee, T. H. (2011). "Intention to Shop Online: A study of Malaysian Baby Boomers". African Journal of Business Management. Vol. 5. (5): pp. 1711-1717.

Linden, S. V. D. (2011). "Charitable Intent: A Moral or Social Construct? A Revised Theory of Planned Behaviour Model”. Current Psychology. Vol. 30: pp. 355-374.

Mahamood., S. M. (2007). "Pembentukan Dana Wakaf Menurut Perspektif Syariah dan Undang-undang serta Aplikasinya di Malaysia". Jurnal Syariah. Vol. 15. pp. 61-83.

Mahmood, N. A. (2013). Potensi Waqaf Korporat dalam Pemilikan Ekuiti Muslim di Malaysia: Kajian di Waqaf An-Nur Corporation. (Master Thesis). Universiti Kebangsaan Malaysia. pp. 7.

Mukhtar, A. and Butt, M. M. (2011). "Intention to Choose Halal Products: The Role of Religiosity". Journal of Islamic Marketing. Vol. 3 (2): pp. 108-120.

Mullan, B. and Wong, C. (2010). "Using the Theory of Planned Behaviour to Design a Food Hygiene Intervention". Food Control. Vol. 21(11): pp. 1524-1529.

Nguyen, P. N. (2011). Inter-Firm Cooperation Under the View of Theory of Planned Behavior: the Case of Vietnam. (Proposal). International Conference on Applied Economics 2011. N.d.

Norris, F. K. and Alan, L. C. (1993). Entrepreneurial Intentions: Applying the Theory of Planned Behaviour. Entrepreneurship \& Regional Development. Vol. 5: pp. 315-330.

Osman, A.F. (2014). An Analysis of Cash Waqf Participation among Young Intellectuals. (Proposal). 9th International Academic Conference. Istanbul. 13 April.

Ramayah, T., Roubah, K., Gopi, M. and Rangel, G. J. (2009). "A Decomposed Theory of Reasoned Action to Explain Intention to Use Internet Stock Trading among Malaysian Investors". Computers in Human Behaviour. Vol. 25. (6): pp. 1222-1230.

Sekaran, U. (2003). Research Methods for Business: A Skill Building Approach. USA: John Wiley \& Sons, Inc.

Shien, J. C. (1998). "The Effects of Attitude, Subjective Norm, and Perceived Behavioural Control on Consumers' Purchase Intentions: The Moderating Effects of Product Knowledge and Attention to Social Comparison Information". Proceedings of the National Science Council, no. 9, pp. 298-308. 
Shih, Y. Y. and Fang, K. (2004). "The Use of a Decomposed Theory of Planned Behaviour to Study Internet Banking in Taiwan". Internet Research. Vol. 14. (3): pp. 213-223.

Simon R. K., Melissa K. H. and Katherine M. W. (2012). "Predictors of Young People's Intentions to Donate Money: An Extended Theory of Planned Behaviour Perspective". Journal of Applied Social Psychology. Vol. 42. (9): pp. 2096-2110.

Sommer, L. (2011). "The Theory of Planned Behaviour and the Impact of Past Behaviour". International Business \& Economics Research Journal. Vol. 10 (1): pp. 91 - 110.

Susan, L. C. H. and Chen, C. F. (2011). "Application of Theory of Planned Behavior on the Study of Workplace Dishonesty". (Proposal). 2010 International Conference on Economics, Business and Management. Manila. N. d.

Teo, T. and Lee, C. B. (2010). "Examining the Efficiency of the Theory of Planned Behavior (TPB) to Understamd Pre-Service Teachers' Intention to Use Technology”. In C.H. Steel, M.J. Keppell, P. Gerbic \& S. Housego (Eds.), Curriculum, Technology \& Transformation for an Unknown Future. Proceeding Ascilite Sydney 2010. pp. 968-972.

Tolma, E. L, Reininger, B. M, Evans, A and Ureda, J. (2006). "Examining the Theory of Planned Behavior and the Construct of Self-Efficacy to Predict Mammography Intention". Health Education \& Behavior. Vol. 33 (2): pp. 233-251.

Truong, Y. (2009). "An Evaluation of the Theory of Planned Behaviour in Consumer Acceptance of Online Video and Television Services”. Electronic Journal Information Systems Evaluation. Vol. 12. (2): pp. 177-186.

Xiao, J. J. and Wu, J. (2006). "Applying the Theory of Planned Behavior to Retain Credit Counseling Clients". (Proposal). Take Charge America Institute for Consumer Financial Education \& Research. 


\section{APPENDICES}

Figure 1: Theoretical Framework

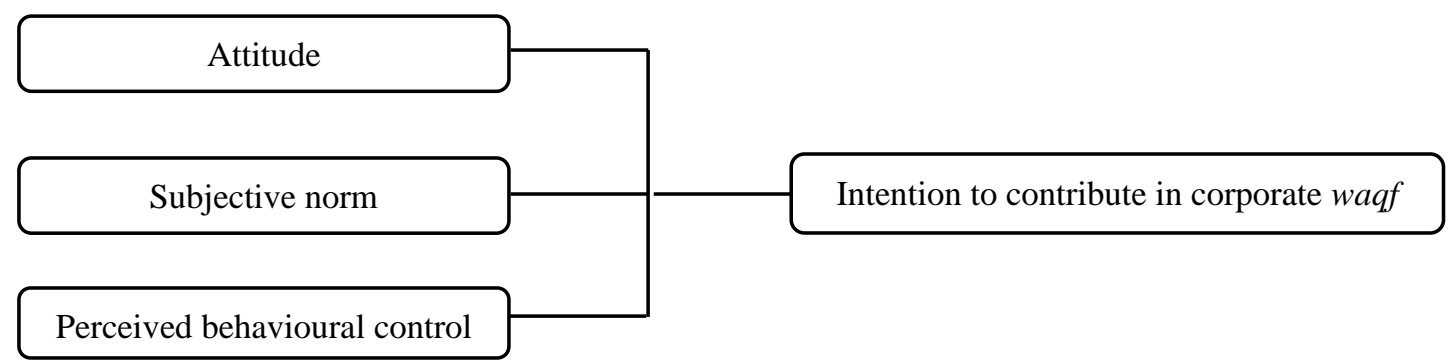

Source: Ajzen (1991)

Table 1: Respondents' Profile

\begin{tabular}{|c|l|c|c|}
\hline Group & & N & Percent \\
\hline Gender & Male & 48 & 32.4 \\
& Female & 100 & 67.6 \\
\hline \multirow{2}{*}{ Age } & 20-30 years & 61 & 41.2 \\
& 31-40 years & 67 & 45.3 \\
& $41-50$ years & 17 & 11.5 \\
& 51-60 years & 2 & 1.4 \\
& 61-70 years & 1 & 0.7 \\
\hline \multirow{2}{*}{ Education } & Secondary school and below & 63 & 42.6 \\
& Diploma/ Certificate & 57 & 38.5 \\
& Undergraduate & 21 & 14.2 \\
& Master & 6 & 4.1 \\
& Ph.D & 1 & 0.7 \\
\hline \multirow{2}{*}{ Salary } & RM2,000 - RM3,000 & 101 & 68.2 \\
& RM3,001 - RM4,000 & 30 & 20.3 \\
& RM4,001 - RM5,000 & 14 & 9.5 \\
& RM5,001 - RM6,000 & 3 & 2.0 \\
\hline
\end{tabular}

Source: Developed for Current Study

Table 2: Descriptive Analysis

\begin{tabular}{|c|c|c|c|}
\hline Variables & Items & Mean & $\begin{array}{c}\text { Std. } \\
\text { Deviation }\end{array}$ \\
\hline \multirow{5}{*}{ Attitude } & Performing corporate waqf course is beneficial. & 3.97 & 0.66 \\
\hline & Performing corporate waqf course is rewarding. & 4.08 & 0.58 \\
\hline & I have positive perception in corporate waqf. & 4.04 & 0.69 \\
\hline & Performing corporate waqf course is a good idea. & 4.05 & 0.67 \\
\hline & I like corporate waqf. & 4.03 & 0.71 \\
\hline \multirow{3}{*}{ Subjective Norm } & $\begin{array}{l}\text { Most people who are important to me think that I } \\
\text { should perform corporate waqf. }\end{array}$ & 3.91 & 0.82 \\
\hline & $\begin{array}{l}\text { My friends would think that I should perform } \\
\text { corporate waqf. }\end{array}$ & 3.93 & 0.82 \\
\hline & $\begin{array}{l}\text { It is expected of me that I should perform corporate } \\
\text { waqf. }\end{array}$ & 3.99 & 0.80 \\
\hline
\end{tabular}




\begin{tabular}{|l|l|c|c|}
\hline \multicolumn{1}{|c|}{ Variables } & \multicolumn{1}{|c|}{ Items } & Mean & $\begin{array}{c}\text { Std. } \\
\text { Deviation }\end{array}$ \\
\hline \multirow{4}{*}{$\begin{array}{l}\text { Perceived Behavioural } \\
\text { Control }\end{array}$} & I have financial resources to perform corporate waqf. & 3.66 & 0.85 \\
\cline { 2 - 5 } & I have the ability to perform corporate waqf. & 3.74 & 0.82 \\
\cline { 2 - 5 } & I have the knowledge to perform corporate waqf. & 3.85 & 0.87 \\
\cline { 2 - 5 } & Performing corporate waqf is within my control. & 3.80 & 0.82 \\
\hline \multirow{4}{*}{$\begin{array}{l}\text { Intention to } \\
\text { Contribute }\end{array}$} & I will choose corporate waqf as a way for my charity. & 4.09 & 0.58 \\
\cline { 2 - 5 } & Overall, I plan to do corporate waqf. & 3.99 & 0.65 \\
\cline { 2 - 5 } & I will recommend corporate waqf to my friends. & 4.05 & 0.68 \\
\cline { 2 - 5 } & $\begin{array}{l}\text { My general intention to perform corporate } \text { waqf } \text { is } \\
\text { higher. }\end{array}$ & 4.13 & 0.59 \\
\cline { 2 - 5 } & I will think opting corporate waqf. & 4.19 & \multicolumn{2}{|c|}{0.63} \\
\hline
\end{tabular}

Source: Developed for Current Study

Table 3: Reliability Analysis

\begin{tabular}{|l|c|c|}
\hline \multicolumn{1}{|c|}{ Variables } & Cronbach's Alpha & Number of Items \\
\hline Attitude & 0.89 & 5 \\
\hline Subjective Norm & 0.94 & 3 \\
\hline Perceived Behaviour Control & 0.95 & 4 \\
\hline Intention to Contribution & 0.91 & 5 \\
\hline
\end{tabular}

Source: Developed for Current Study

Table 4: Regression Analysis (Model Summary)

\begin{tabular}{|c|c|c|c|c|}
\hline Model & R & R Square & Adjusted R Square & Std. Error of the Estimate \\
\hline 1 & 0.75 & 0.56 & 0.55 & 0.36 \\
\hline
\end{tabular}

Source: Developed for Current Study

Table 5: Regression Analysis (Coefficients)

\begin{tabular}{|l|l|c|c|c|c|}
\hline & \multicolumn{1}{|c|}{ Hypotheses } & Beta & $\boldsymbol{t}$-value & $\boldsymbol{p}$-value & Supported? \\
\hline H1 & $\begin{array}{l}\text { There is a positive relationship between attitude and } \\
\text { people's intention to contribute in corporate } \text { waqf. }\end{array}$ & 0.44 & $5.94^{*}$ & 0.00 & Yes \\
\hline H2 & $\begin{array}{l}\text { There is a positive relationship between subjective norm } \\
\text { and people's intention to contribute in corporate waqf. }\end{array}$ & 0.30 & $3.43^{*}$ & 0.01 & Yes \\
\hline H3 & $\begin{array}{l}\text { There is a positive relationship between perceived } \\
\text { behavioural control and people's intention to contribute } \\
\text { in corporate waqf. }\end{array}$ & 0.13 & $1.75^{* *}$ & 0.08 & Not \\
\hline
\end{tabular}

Source: Developed for Current Study

Figure 2: Final Model with Regression Weights

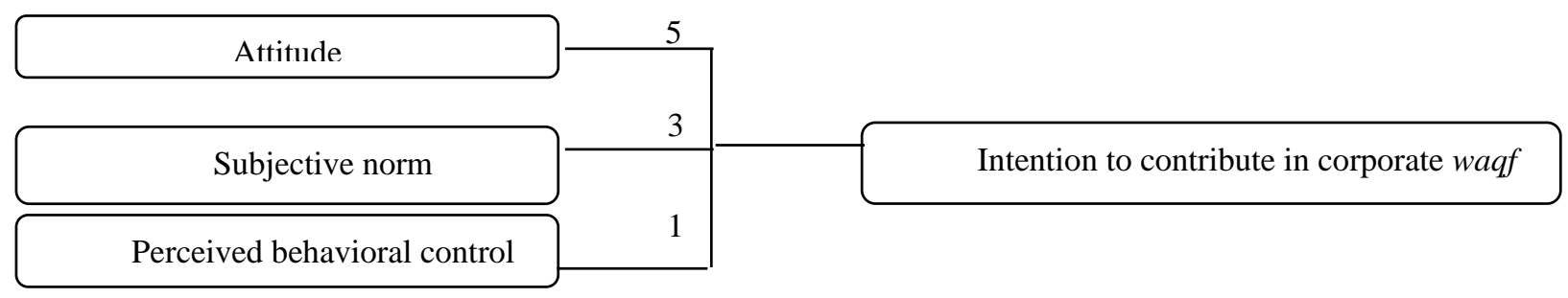

Note: *Significant, **Not Significant

Source: Developed for Current Study 